ACTA SCIENTIFIC MICROBIOLOGY (ISSN: 2581-3226)

Volume 4 Issue 10 October 2021

Research Article

\title{
Comparison of ZN Microscopy, Culture on LJ Media and Gene Xpert MTB/RIF Assay in Diagnosis of Extra-Pulmonary Tuberculosis
}

\section{AS Boinwad ${ }^{1}$ and JA Iravane ${ }^{2 *}$}

${ }^{1}$ Assistant Professor at Swami Ramanand Teerth Rural Government Medical College, Ambajogai, Maharashtra, India

${ }^{2}$ Professor and Head of Department, Government Medical College, Aurangabad, India

*Corresponding Author: Dr. JA Iravane, Professor and Head of Department, Department of Microbiology, Government Medical College, Aurangabad, Maharashtra, India.
Received: August 26, 2021

Published: September 20, 2021

(C) All rights are reserved by AS Boinwad and JA Iravane.

\section{Abstract}

Tuberculosis is caused by Mycobacterium tuberculosis and classified as pulmonary tuberculosis (PTB) and Extra Pulmonary tuberculosis (EPTB). EPTB account for 15-20 \% cases of tuberculosis. EPTB diagnosis is challenging due to inadequate sample volume, pauci-bacillary nature and unusual clinical presentation. This study determined the role of Gene Xpert MTB/RIF assay in diagnosis of EPTB and compared results with conventional smear microscopy and culture on LJ media.

All the samples coming to our laboratory during January 2015 to June 2016 were processed with Gene Xpert MTB/RIF assay, Smear microscopy and LJ media culture. Total samples examined were 514. 90(17.51\%) samples were positive by Gene Xpert MTB/ RIF assay of these 15 samples shows Rifampicin resistance. Samples which were positive by culture and smear microscopy were 58(11.28\%) and 28(5.45\%) respectively.

To conclude, we can say that Gene Xpert MTB/RIF assay is the novel test for rapid diagnosis of Extra Pulmonary Tuberculosis.

\section{Introduction}

Tuberculosis is an ancient disease and it is a global public health problem till date. The disease is caused by Mycobacterium tuberculosis. Tuberculosis generally affects lungs, but it can also affect any other organ of body such as bones, lymph nodes, central nervous system, kidneys etc. When tubercle bacilli affects any other part of body, other than the lungs, it is called as Extra Pulmonary Tuberculosis (EPTB). The last decade has witnessed shifting trends in TB infection, with extra pulmonary tuberculosis (EPTB) emerging as an important entity [1]. Extra-pulmonary tuberculosis most commonly seen in immunosuppressed persons and young children. The consequences of some forms of extra pulmonary tuberculosis (EPTB)such as TB meningitis, myocardial TB, may be life threaten- ing, and thus timely diagnosis and initiation of appropriate therapy are crucial [2].

The burden of extra-pulmonary tuberculosis (EPTB) is high, ranging from $15-20 \%$ of all tuberculosis (TB) cases in HIV negative patients, while in HIV positive it is than $50 \%$ of all new TB cases $[4,5]$. The diagnosis of EPTB is challenging due to inadequate clinical sample volumes available and paucibacillary nature of the biological samples and unusual clinical presentation [2,6]. Diagnosis of extra pulmonary tuberculosis(EPTB) is not always possible with conventional methods, due to the long time required and the paucibacillary nature of samples; hence the need of rapid molecular methods [1]. 
Gene Xpert MTB/RIF assay is a type of CB-NAAT based novel test for the diagnosis of EPTB and simultaneous detection of rifampicin resistance with very high sensitivity. Since its introduction to research settings in 2010, several investigators have tested the accuracy of this test in Non-respiratory samples for the diagnosis of various forms of EPTB. WHO in the year 2013 recommended use of Xpert MTB/RIF assay in the diagnosis of extra pulmonary tuberculosis. 9 Isolation of Mycobacterium tuberculosis on LJ media requires 6-8 weeks' time and for drug resistance study it requires 8-12 weeks' time but in case of Gene Xpert the results are obtained in nearly two hours.

In this study we determined the role of Gene Xpert MTB/RIF assay in diagnosis of all forms of EPTB and compared the results with the conventional smear microscopy and culture on LJ media.

\section{Material and Methods}

The main aim of the study was to diagnose Extra Pulmonary Tuberculosis cases with simultaneous detection of MDR cases. A study was conducted in a tertiary care hospital on clinical specimens collected over a period of 1 and $1 / 2$ year, January 2015 to June 2016. All the samples which were sent by the clinician to our laboratory were accepted with fully filled requisition form. The samples was opened in the biosafety cabinet.

\section{Sample collection}

Different samples depending upon the site of involvement were collected by physicians as per the WHO guidelines and was accepted at the laboratory at room temperature.

\section{Specimen processing}

All the samples received in the laboratory were divided into two parts. One part is used for microscopy and culture and another part for Gene Xpert assay. The Xpert MTB/RIF assay was used directly on CSF specimens and homogenized extra pulmonary specimens (from biopsies of lymph nodes or other tissues) or on decontaminated specimens. Whenever possible, specimens was processed as early as possible and if delay was unavoidable it was stored at 2-8 ${ }^{\circ} \mathrm{C}$ (the maximum time for storage and processing was 7 days).

\section{Microscopy}

For microscopy smear were prepared in the biosafety cabinet. Let it air dry and then shifted to the room where ZN staining was to be done. Procedure of $\mathrm{ZN}$ staining was done according to the RN-
TCP guidelines. All the smears were scanned and grading was done according to the guidelines provided by the RNTCP.

\section{Culture}

The samples were inoculated on the LJ media in the biosafety cabinet. After inoculation the LJ slopes were incubated at 37, 45 and at room temperature. All slopes were observed for the presence of growth for every day, till first week and then every week till 8 weeks.

\section{Gene Xpert MTB/RIF assay}

This test is done for the various samples according to the guidelines available as described below

Lymph nodes and other tissues: For tissue sample processing first of all tissue was cut into small pieces in a sterile homogeniser. Then approximately $2 \mathrm{ml}$ of sterile phosphate buffer (PBS) was added to it and again the solution of tissue and PBS was grinded using homogeniser, until a homogeneous suspension was obtained. Approximately $0.7 \mathrm{ml}$ of the homogenized tissue specimen was transferred with the help of transfer pipette, to a sterile, conical screw-capped tube. (if clumps were still there transferring them would be strictly avoided). To $0.7 \mathrm{ml}$ of homogenized tissue, a double volume of the Xpert MTB/RIF Sample Reagent (1.4 ml) was added by using pipette. The tube was shaken Vigorously 10 to 20 times or vortex for at least 10 seconds. Incubated for 10 minutes at room temperature, and then again specimen was shaken properly. The specimen was incubated at room temperature for an additional 5 minutes. Using a fresh transfer pipette, $2 \mathrm{ml}$ of the processed sample was transferred to the Xpert MTB/RIF cartridge. Following the manufacturer's instructions. The cartridge was loaded into the GeneXpert instrument.

Body fluids: For the body fluids there were no need of decontamination procedure. The sample was directly processed according to the Xpert MTB/RIF instruction manual.

Cerebrospinal fluid (CSF): The preferred processing method for CSF in Xpert MTB/RIF depends on the volume of specimen available for testing. Blood-stained and xanthochromic CSF specimens may cause false-negative results from Xpert MTB/RIF so before processing specimens were carefully observed for gross and if it was blood stained or xanthochromic, specimen was recalled by contacting the treating clinician 


\section{Results}

All the samples received to the laboratory were processed by all the three methods i.e. ZN Microscopy, Culture on LJ media and Gene Xpert MTB/RIF assay. Total samples received were 514, of which samples positive by Gene Xpert MTB/RIF assay were 90, samples positive by Culture were 58 and samples positive by ZN Smear microscopy were 25 as shown in chart 1 .

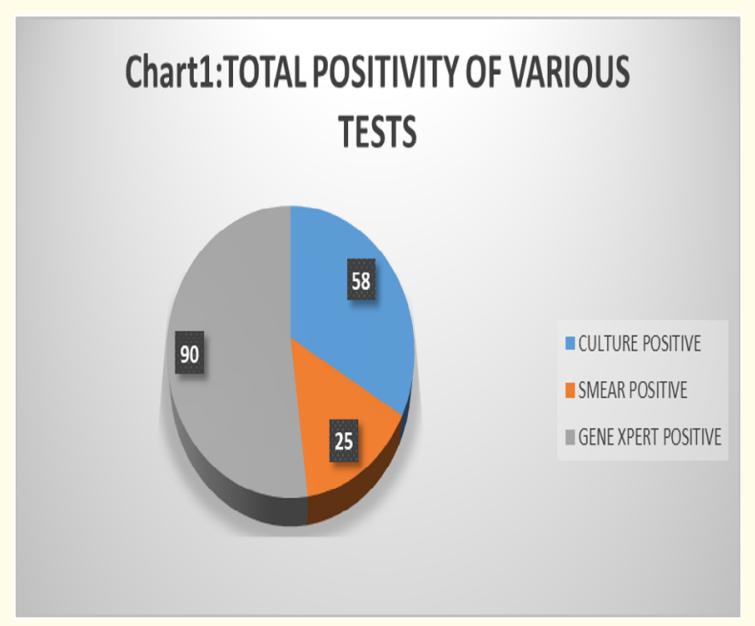

Chart 1

Number of samples positive by gene xpert are highest followed by the culture and then smear. Positivity of Gene Xpert, LJ culture and Microscopy is demonstrated in the table 1.

\begin{tabular}{|c|c|c|c|c|c|c|c|}
\hline & \multirow{2}{*}{$\begin{array}{c}\text { Total } \\
\text { speci- } \\
\text { mens }\end{array}$} & \multicolumn{2}{|c|}{$\begin{array}{c}\text { Gene xpert } \\
\text { positive }\end{array}$} & \multicolumn{2}{|c|}{$\begin{array}{c}\text { Zn smear } \\
\text { positive }\end{array}$} & \multicolumn{2}{|c|}{$\begin{array}{c}\text { Culture } \\
\text { positive }\end{array}$} \\
\cline { 5 - 8 } & $\begin{array}{c}\text { Num- } \\
\text { in labora- } \\
\text { tory }\end{array}$ & ber & & $\begin{array}{c}\text { Num- } \\
\text { ber }\end{array}$ & $\%$ & $\begin{array}{c}\text { Num- } \\
\text { ber }\end{array}$ & $\%$ \\
\hline $\begin{array}{c}\text { Ascitic } \\
\text { fluid }\end{array}$ & 30 & 2 & $7 \%$ & 1 & $3 \%$ & 2 & $7 \%$ \\
\hline $\begin{array}{c}\text { Cold } \\
\text { abscess }\end{array}$ & 3 & 3 & $100 \%$ & 1 & $33 \%$ & 3 & $100 \%$ \\
\hline CSF & 78 & 9 & $12 \%$ & 2 & $3 \%$ & 4 & $5 \%$ \\
\hline $\begin{array}{c}\text { Gastric } \\
\text { lavage }\end{array}$ & 149 & 8 & $5 \%$ & 2 & $1 \%$ & 6 & $4 \%$ \\
\hline $\begin{array}{c}\text { Knee } \\
\text { joint fluid }\end{array}$ & 3 & 1 & $33 \%$ & & $0 \%$ & 1 & $33 \%$ \\
\hline $\begin{array}{c}\text { Paracolic } \\
\text { abscess }\end{array}$ & 1 & & $0 \%$ & & $0 \%$ & & $0 \%$ \\
\hline $\begin{array}{c}\text { Pericar- } \\
\text { dial fluid }\end{array}$ & 9 & 1 & $11 \%$ & 1 & $11 \%$ & 1 & $11 \%$ \\
\hline
\end{tabular}

\begin{tabular}{|c|c|c|c|c|c|c|c|}
\hline $\begin{array}{c}\text { Pleural } \\
\text { fluid }\end{array}$ & 160 & 35 & $22 \%$ & 14 & $9 \%$ & 23 & $14 \%$ \\
\hline PUS & 34 & 21 & $62 \%$ & 4 & $12 \%$ & 13 & $38 \%$ \\
\hline Tissue & 33 & 9 & $27 \%$ & & $0 \%$ & 4 & $12 \%$ \\
\hline Urine & 14 & 1 & $7 \%$ & & $0 \%$ & 1 & $7 \%$ \\
\hline $\begin{array}{c}\text { Grand } \\
\text { total }\end{array}$ & 514 & 90 & $18 \%$ & 25 & $5 \%$ & 58 & $11 \%$ \\
\hline
\end{tabular}

Table 1: Positivity of gene Xpert, LJ culture and ZN smear microscopy in various extra-pulmonary samples.

\begin{tabular}{|c|c|c|c|}
\hline \multirow{2}{*}{} & \multicolumn{2}{|c|}{ Culture result } & Grand \\
\cline { 2 - 3 } & Positive & NO growth (NG) & Total \\
\hline Gene Xpert positive & 58 & 32 & 90 \\
\hline Gene Xpert negative & 0 & 424 & 424 \\
\hline Grand Total & 58 & 456 & 514 \\
\hline
\end{tabular}

Table 2: Comparison of gene Xpert MTB/RIF assay with LJ culture.

As described in the values of table 2: The sensitivity, specificity, positive predictive value (PPV), negative predictive value (NPV) of Gene Xpert as compared to LJ culture were as follows-

(Where $\mathrm{A}=$ Gene Xpert as well as culture positive, $\mathrm{B}=$ Culture negative, Gene Xpert positive, $\mathrm{C}=$ Culture positive, Gene Xpert negative, $\mathrm{D}=$ Culture negative, Gene Xpert negative)

Sensitivity: A/(A+B) X 100=58/58+0 X $100=100 \%$

Specificity $=D /(D+C) \times 100=424 / 456 \times 100=0.929 \times 100=92.9 \%$

Positive predicyive value $(\mathrm{PPV})=\mathrm{A}(\mathrm{A}+\mathrm{B}) \times 100=58 / 90 \times 100=$ $0.644 \times 100=64.4 \%$

Negative predictive value $=D /(D+C) \times 100=424 / 424 \times 100=100 \%$.

\begin{tabular}{|c|c|c|c|}
\hline & \multicolumn{2}{|c|}{ ZN smear microscopy } & \\
\cline { 2 - 4 } & Positive & Negative & Grand Total \\
\hline Gene Xpert positive & 24 & 66 & 90 \\
\hline Gene Xpert negative & 1 & 423 & 424 \\
\hline Grand Total & 25 & 489 & 514 \\
\hline
\end{tabular}

Table 3: Comparison of gene xpert with ZN smear microscopy (Where $\mathrm{A}=$ Gene Xpert as well as smear positive, $\mathrm{B}=$ Smear Negative, Gene Xpert positive, $\mathrm{C}=$ smear positive, Gene Xpert negative, $\mathrm{D}$ = smear negative, Gene Xpert negative)

Sensitivity $=a /(a+b) \times 100=24 / 25 \times 100=0.96 \times 100=96 \%$ Specificity $=d /(d+c) \times 100=423 / 489 \times 100=0.865 \times 100=86.5 \%$ $\mathrm{PPV}=\mathrm{a} /(\mathrm{a}+\mathrm{b}) \times 100=24 / 66 \times 100=0.363 \times 100=36.3 \%$ $N P V=d /(d+c) \times 100=423 / 424 \times 100=0.997=99.7 \%$ 


\begin{tabular}{|c|c|c|c|}
\hline & \multicolumn{2}{|c|}{ ZN smear negative } & Grand Total \\
\cline { 2 - 4 } & $\begin{array}{c}\text { Culture } \\
\text { positive }\end{array}$ & $\begin{array}{c}\text { Culture } \\
\text { negative }\end{array}$ & \\
\hline Gene xpert positive & 34 & 32 & 66 \\
\hline Gene xpert negative & 0 & 423 & 423 \\
\hline Grand Total & 34 & 455 & 489 \\
\hline
\end{tabular}

Table 4: Comparison of gene xpert with LJ culture in smear negative cases.

Where $\mathrm{A}=$ Culture as well as gene Xpert positive, $\mathrm{B}=$ Culture negative, Gene Xpert positive, $\mathrm{C}=$ Culture positive, Gene Xpert negative, $\mathrm{D}=$ Culture negative, Gene Xpert negative)

SENSITIVITY 100\%, SPECIFICITY was 92.9\%, PPV= 51.5\%, NPV= $100 \%$.

\begin{tabular}{|c|c|c|c|}
\hline & \multicolumn{2}{|c|}{ Smear positive } & \multirow{2}{*}{ Grand total } \\
\cline { 2 - 3 } & $\begin{array}{c}\text { LJ culture } \\
\text { positive }\end{array}$ & $\begin{array}{c}\text { LJ culture } \\
\text { negative }\end{array}$ & \\
\hline Gene xpert positive & 24 & 0 & 24 \\
\hline Gene xpert negative & 0 & 1 & 1 \\
\hline Grand Total & 24 & 1 & 25 \\
\hline
\end{tabular}

Table 5: Comparison of gene xpert with culture in smear positive cases.

Sensitivity $=100 \%$, Specificity $=100 \%$, PPV $=100 \%$, NPV $=100 \%$.

\begin{tabular}{|c|c|c|}
\hline Specimen type & Sensitivity & Specificity \\
\hline Ascitic fluid & $100 \%$ & $100 \%$ \\
\hline Cold abscess & $100 \%$ & Not estimable \\
\hline CSF & $100 \%$ & $93.3 \%$ \\
\hline Gastric lavage & $100 \%$ & $98.6 \%$ \\
\hline Joint fluid & $100 \%$ & $100 \%$ \\
\hline Pericardial fluid & $100 \%$ & $100 \%$ \\
\hline Pleural fluid & $100 \%$ & $91.2 \%$ \\
\hline Pus & $100 \%$ & $61.9 \%$ \\
\hline Tissue & $100 \%$ & $82.7 \%$ \\
\hline Urine & $100 \%$ & $100 \%$ \\
\hline
\end{tabular}

Table 6: Sensitivity and specificities of all the sample types.

\section{Discussion}

Extra-pulmonary tuberculosis accounts for 15- 20\% of burden of TB globally. Low yield of smear and culture attributed to paucibacillary nature of specimen [7]. Conventional culture methods were very time consuming and require Biosafety setup and trained laboratory personnel. Therefore there was a need for newer and faster diagnostic methods and recent attention has been given to nucleic acid amplification techniques like Gene Xpert (CBNAAT) [8]. The Gene xpert technique enables diagnosis of TB and simultaneous assessment of rifampicin resistance to be completed within 2 hour. The extra advantage is the convenience of sample processing where unprocessed sputum samples as well as clinical specimens from extra pulmonary sites can be directly assayed [9].

In this study we compared the results of Gene Xpert MTB/RIF assay with the LJ culture and ZN smear microscopy both, for diagnosis of Extra-pulmonary tuberculosis. We used LJ culture as reference standard for diagnosis of TB [10-31].

\begin{tabular}{|l|c|c|c|c|c|}
\hline & $\begin{array}{c}\text { Our } \\
\text { study }\end{array}$ & $\begin{array}{c}\text { Ahmed., } \\
\text { et al. }\end{array}$ & $\begin{array}{c}\text { Vadwai., } \\
\text { et al. }\end{array}$ & $\begin{array}{c}\text { Zeka., } \\
\text { et al. }\end{array}$ & $\begin{array}{c}\text { E.tortoli., } \\
\text { et al. }\end{array}$ \\
\hline Sensitivity & 100 & 77.3 & 73 & 100 & 79 \\
\hline Specificity & 92.9 & 98.2 & 86 & 97 & 97.3 \\
\hline
\end{tabular}

Table a

There were various studies showing different type of positivity among various extrapulmonary samples. Some studies are comparable to our study with slight variations were described below.

In most of the cases the sensitivity ranges from about $52-100 \%$ and specificity ranges from $73-100 \%[11,13,16,22,29-31]$ the present study results comparable with all these studies.

Overall sensitivity of Gene Xpert MTB/RIF Assay in various studies was as follows

The following table shows the percent positivity by various methods

\begin{tabular}{|c|c|c|c|c|}
\hline & $\begin{array}{c}\text { Ahemad., } \\
\text { et al. }\end{array}$ & $\begin{array}{c}\text { Avshia., } \\
\text { et al. }\end{array}$ & $\begin{array}{c}\text { Imran., } \\
\text { et al. }\end{array}$ & $\begin{array}{c}\text { Our } \\
\text { study }\end{array}$ \\
\hline Gene Xpert & 37 & 37 & 22.5 & 17.5 \\
\hline ZN Stain & 12 & 36 & 7.5 & 4.8 \\
\hline LJ Culture & 17 & - & 10 & 11.2 \\
\hline
\end{tabular}

Table b 
In our study we tested 30 samples of ascitic fluid, 3 samples of cold abscess, and 78 of CSF, 149 gastric lavage, 3 joint fluids, 1 paracolic abscess, 160 pleural fluids, 34 pus, 33 tissue and 14 urine samples. positivity of culture was $7 \%(2 / 30), 100 \%(3 / 3)$, 5\%(4/74), 4\%(6/149), 33\%(1/3), 0\%, 11\%(1/9), 14\%(23/160), $38 \%(13 / 33), 12 \%(4 / 33), 7 \%(1 / 14)$ for ascitic fluid, cold abscess, CSF, gastric lavage, joint fluid, paracolic abscess, pleural fluid, pus, tissue and urine respectively.

Positivity of Gene Xpert was highest in case of aspirate from cold abscess $100 \%$ (3/3) followed by pus $62 \%(21 / 34), 33 \%(1 / 3)$ joint fluid, 27\% (9/33) for tissue, 22\%(35/160) pleural fluids, $12 \%(9 / 78) \mathrm{CSF}, 11 \%$ for pericardial fluid, and $5 \%$ for gastric lavage. In case of pus samples we found slightly higher sensitivity (62\%) as compared to the study by Avashia., et al. (56.7\%) [10].

A systematic review and meta-analysis of commercial nucleic acid amplification tests for the diagnosis of tuberculous meningitis showed a combined average sensitivity of $56 \%$ and specificity of 98\% [35]. Lower sensitivity and higher specificity was observed as compared to our study for CSF. The sensitivity and specificity in smear positive and smear negative samples were also analysed in our study and found to be $100 \%$ sensitive as well as specific in case of smear positive sample and in smear negative sensitivity is $100 \%$ but specificity was $92.9 \%$. In a similar study by Vadwai, the sensitivity of expert assay was $64 \%$ for smear negative cases and $96 \%$ for smear positive cases with a specificity of $99.6 \%$ [30]. In present study we got the higher sensitivity (100\%) in smear negative samples than in a study by Vadwai (64\%), but slightly lower specificity (92.9\%) as compared to (99.6\%) Vadwai study.

Sensitivity in smear negative cases varies from 58 to $92 \%$ in most of the studied $[22,29,31,36,37]$. Overall we observed higher sensitivity.

In present study sensitivity was $100 \%$ in all the cases, but specificity varies. In most of the samples overall specificity was above $90 \%$ except for two samples pus and tissue in which it was $61.9 \%$ and $82.7 \%$. In a another study sensitivity in pus samples was $85.7 \%$ and specificity was $94.6 \%$ [29] which was higher than in the present study. In case of CSF samples we got the results of specificity comparable to a meta-analysis by Denkinger., et al. but higher sensitivity was observed in our study [16]. For pleural fluid results in present study observed sensitivity of $100 \%$ and speci- ficity of $91.2 \%$ which shows higher sensitivity and slightly lower specificity as compared to other studies.

For reporting of MDR we had done Gene Xpert test and samples positive for rifampicin resistance are reported as MDR. From the total 90 positive by gene Xpert 14 were detected as rifampicin resistant.

\section{Conclusion}

We can conclude from the comparison done in this study that Gene Xpert assay is efficient in detecting all types of specimens in extra pulmonary tuberculosis as compared to conventional culture on LJ media and Smear microscopy. From the discussion we can say that we got the higher sensitivity compared to most of the studies, but slightly lower specificity was observed in our study.

The simplicity, sensitivity, speed and automation make this technique an attractive tool for diagnosis of extra-pulmonary specimens and Rifampicin resistance especially in smear negative cases of clinically suspected TB. As diagnosis is compromised in these cases due to low bacterial load, paucibacillary nature and less quantity of specimen. We observed that Gene Xpert gives higher positivity rates as compared to LJ culture and ZN smear with higher sensitivity and specificity. So from this observation we can conclude than Gene Xpert can be used as initial test to diagnose all forms of EPTB specimens. High sensitivity in smear positive cases supports its use in non-respiratory samples in principle [16].

\section{Bibliography}

1. Jain A. "Extra pulmonary tuberculosis: A diagnostic dilemma". Indian Journal of Clinical Biochemistry 26.3 (2011): 269-273.

2. Pai M and Nathavitharana R. "Extrapulmonary tuberculosis: new diagnostics and new policies". Indian Journal of Chest Diseases and Allied Sciences 56.2 (2014): 71-73.

3. WHO. Global Tuberculosis Report 2016. Cdc 2016. 2016 (Global TB Report 2016) (2016).

4. Golden MP and Vikram HR. "Extrapulmonary tuberculosis: An overview". American Family Physician 72.9 (2005): 17611768.

5. Sharma SK and Mohan A. "Extrapulmonary Tuberculosis". Indian Journal of Immunology and Respiratory Medicine (2004): 316-353. 
6. Mehta PK., et al. "Diagnosis of extrapulmonary tuberculosis by PCR". FEMS Immunology and Medical Microbiology 66.1 (2012): 20-36.

7. Chakravorty S., et al. "Diagnosis of Extrapulmonary Tuberculosis by Smear, Culture, and PCR Using Universal Sample Processing Technology Diagnosis of Extrapulmonary Tuberculosis by Smear, Culture, and PCR Using Universal Sample Processing Technology". Journal of Clinical Microbiology 43.9 (2005): 4357-4362.

8. Desai SL and Pol S. "A comprehensive comparision of mpb64 based pcr assay versus microscopy and culture in the diagnosis of clinically suspected cases of extrapulmonary tuberculosis". (2015).

9. WHO. Automated Real-Time Nucleic Acid Amplification Technology for Rapid and Simultaneous Detection of Tuberculosis and Rifampicin Resistance: Xpert MTB/RIF Assay for the Diagnosis of Pulmonary and Extrapulmonary TB in Adults and Children: Policy Update (2013): 97.

10. Avashia S., et al. "Comparison of conventional methods with gene xpert mtb/rif assay for rapid detection of mycobacterium tuberculosis and rifampicin resistance in extra-pulmonary samples" 4.2 (2016): 181-185.

11. Iram S., et al. "Rapid diagnosis of tuberculosis using Xpert MTB/RIF assay - Report from a developing country". Pakistan Journal of Medical Science 31.1 (2014): 105-110.

12. Bajrami R., et al. "Comparison of genexpert MTB/RIF and conventional methods for the diagnosis of tuberculosis in Kosovo". Journal of Infection in Developing Countries 10.4 (2016): 418-422.

13. Balcha TT., et al. "Intensified tuberculosis case-finding in HIVpositive adults managed at ethiopian health centers: Diagnostic yield of xpert MTB/RIF compared with smear microscopy and liquid culture". PLoS One 9.1 (2014).

14. Bates M., et al. "Assessment of the Xpert MTB/RIF assay for diagnosis of tuberculosis with gastric lavage aspirates in children in sub-Saharan Africa: A prospective descriptive study". Lancet Infectious Disease 13.1 (2013): 36-42.

15. Chakravorty S and Tyagi JS. "Novel multipurpose methodology for detection of mycobacteria in pulmonary and extrapulmonary specimens by smear microscopy, culture, and PCR". Journal of Clinical Microbiology 43.6 (2005): 2697-2702.
16. Denkinger CM., et al. "Xpert MTB/RIF assay for the diagnosis of extrapulmonary tuberculosis: A systematic review and meta-analysis". European Respiratory Journal 44.2 (2014): $435-446$.

17. Helb D., et al. "Rapid detection of Mycobacterium tuberculosis and rifampin resistance by use of on-demand, near-patient technology". Journal of Clinical Microbiology 48.1 (2010): 229237.

18. Hillemann D., et al. "Rapid molecular detection of extrapulmonary tuberculosis by the automated genexpert MTB/RIF system". Journal of Clinical Microbiology 49.4 (2011): 1202-1205.

19. Kashif Munir M., et al. "Comparison of Ziehl Neelsen Microscopy with GeneXpert for Detection of MycobacteriumTuberculosis". IOSR Journal of Dental and Medical Sciences 14.11 (2015): 2279-2861.

20. Kn P., et al. "Use of GeneXpert Assay for Diagnosis of Tuberculosis From Body Fluid Specimens, a 2 Years Study" (2016): $1-4$.

21. Ligthelm LJ., et al. "Xpert MTB/RIF for rapid diagnosis of tuberculous lymphadenitis from fine-needle-aspiration biopsy specimens". Journal of Clinical Microbiology 49.11 (2011): 3967-3970.

22. Maynard-Smith L., et al. "Diagnostic accuracy of the Xpert MTB/RIF assay for extrapulmonary and pulmonary tuberculosis when testing non-respiratory samples: a systematic review. BMC Infectious Disease 14.1 (2014): 709.

23. Meawed TE and Shaker A." Assessment of diagnostic accuracy of Gene Xpert MTB/RIF in diagnosis of suspected retreatment pulmonary tuberculosis patients". Egyptian Journal of Chest Diseases and Tuberculosis 65 (2016): 637-641.

24. Rufai SB., et al. "Performance of xpert MTB/RIF assay in diagnosis of pleural tuberculosis by use of pleural fluid samples". Journal of Clinical Microbiology 53.11 (2015): 3636-3638.

25. Rufai S., et al. "Performance of Xpert MTB/RIF on ascitic fluid samples for detection of abdominal tuberculosis". Journal of Laboratory Physicians 9.1 (2017): 47.

26. Sehgal IS., et al. "Diagnostic Performance of Xpert MTB / RIF in Tuberculous Pleural Effusion : Systematic Review and Meta-analysis". Journal of Clinical Microbiology 54.4 (2016): 1133-1136. 
27. Sharma SK., et al. "Evaluating the diagnostic accuracy of xpert MTB/RIF assay in pulmonary tuberculosis". PLoS One (2015).

28. Shrestha P., et al. "The Application of GeneXpert MTB/RIF for Smear-Negative TB Diagnosis as a Fee-Paying Service at a South Asian General Hospital". Tuberculosis Research and Treatment 2015 (2015): 102430.

29. Vadwai V., et al. "Xpert MTB/RIF: A new pillar in diagnosis of extrapulmonary tuberculosis?". Journal of Clinical Microbiology 49.7 (2011): 2540-2545.

30. Tortoli E., et al. "Clinical validation of Xpert MTB/RIF for the diagnosis of extrapulmonary tuberculosis". European Respiratory Journal 40.2 (2012): 442-447.

31. Zeka AN., et al. "Evaluation of the GeneXpert MTB/RIF assay for rapid diagnosis of tuberculosis and detection of rifampin resistance in pulmonary and extrapulmonary specimens". Journal of Clinical Microbiology 49.12 (2011): 4138-4141.

32. Noussair L., et al. "Early diagnosis of extrapulmonary tuberculosis by a new procedure combining broth culture and PCR". Journal of Clinical Microbiology 47.5 (2009): 1452-1457.

33. Lawn SD and Nicol MP. "Xpert ® MTB / RIF assay: development, evaluation and implementation of a new rapid molecular diagnostic for tuberculosis and rifampicin resistance". Future Microbiology 6.9 (2011): 1067-1082.

34. Mid-prevalence areas in the lung and extrapulmonary tuberculosis diagnosis.

35. Pai M., et al. "Diagnostic accuracy of nucleic acid amplification tests for tuberculous meningitis: a systematic review and meta-analysis". Lancet Infectious Disease 3.10 (2003): 633-643.

36. Teo J., et al. "Comparison of two nucleic acid amplification assays, the Xpert MTB/RIF assay and the amplified mycobacterium tuberculosis direct assay, for detection of Mycobacterium tuberculosis in respiratory and nonrespiratory specimens". Journal of Clinical Microbiology 49.10 (2011): 3659-3662.

37. Agrawal M., et al. "Comparative study of GeneXpert with ZN stain and culture in samples of suspected pulmonary tuberculosis". Journal of Clinical and Diagnostic Research 10.5 (2016): DC09-DC12.

Volume 4 Issue 10 October 2021

(C) All rights are reserved by AS Boinwad and JA Iravane. 